\title{
POLITECNICO DI MILANO. PROGRAME DE ARHITECTURĂ ȘI ACTIVITĂȚI
}

Conf. dr. arh. Cristina Șerban

se_cris@yahoo.com

POLITECTNICO DI MILANO

MILANO, INTALIA

03/2019-04/2019 


\section{OFERTA EDUCAȚIONALĂ}

Universitatea Politehnică din Milano este cea mai prestigioasă universitate din Italia, fiind una dintre primele 10 universități din Europa și clasându-se printre primele 15 universități din lume. Din structura universității fac parte 4 școli - Arhitectură, Urbanism și Ingineria Construcțiilor, Design și Inginerie, organizate în 7 campusuri - Milano (Leonardo și Bovisa), Piacenza, Mantova, Lecco, Como și Cremona. Cursurile ce pot fi urmate sunt: cursuri de Licență (3 ani), cursuri de Master (2 ani) și Doctorat. Există și posibilitatea de a alege o direcție de studiu de Licență și Master fără întrerupere (5 ani), dar în această variantă trebuie reluată admiterea în cazul unei întreruperi.

\section{PROGRAME ARHITECTURALE}

Încă din al 2-lea an de Licență, primul an fiind unul comun, studenții pot opta pentru discipline și activități ce-i pot orienta pe direcții către specializări precum Urbanism, Ingineria Construcțiilor sau Design Arhitectural. Dacă primelor două direcții le corespund apoi Mastere dedicate, licențiații școlii de arhitectură au posibilitatea de a alege între

Fig. 1. Oferta educațională a programelor arhitecturale. Sursa: imagine preluată din broșura universității POLITECNICO DI

MILANO, Arhitectural Programmes - School of Architecture, Urban Planning, Construction Engineering, pag.101; dreapta - standurile departamentelor școlii de Design in timpul evenimentului OPEN DAY din campusul Bovisa: Design Interior, Design Industrial, Communication Design și Fashion Design. Surse foto: autorul

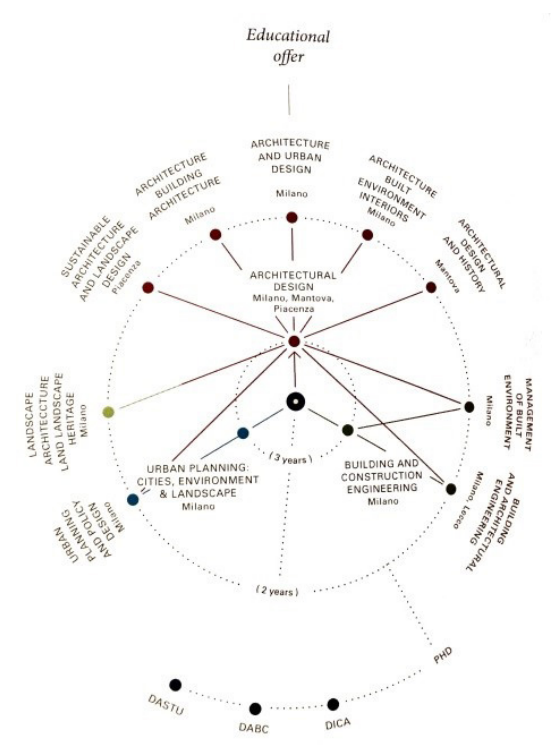

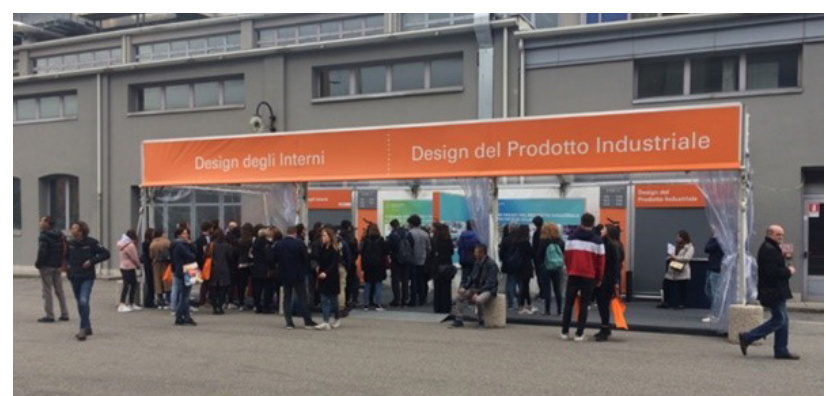

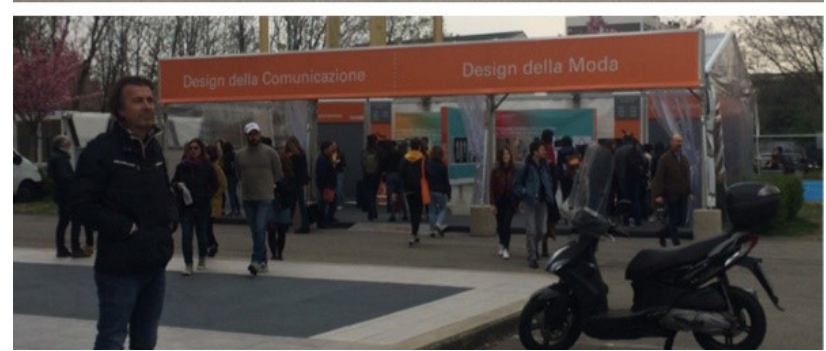


mai multe opțiuni de Master după finalizarea primilor 3 ani, așa cum se poate vedea în schema din Fig. 1 stânga. Aceste studii se regăsesc în campusurile din Milano (Leonardo), Piacenza, Lecco și Mantova.

Școala de Design, ce oferă specializări în Design Interior, Design Industrial, Fashion Design și Communication Design are o programă separată de cea arhitecturală și se desfășoară în campusul Bovisa din Milano. Un student care urmează Licența la Design Interior la Bovisa, nu poate urma Masterul de Arhitectura Mediului Construit Interior (Fig. 1 dreapta) și, astfel, acesta nu primește drept de semnătură pentru arhitecții de interior.

Școala de Design este apreciată ca fiind pe primul loc în Italia, pe locul 3 în Europa și pe locul 6 în lume din categoria universităților de Artă și Design.

\section{ALTE ACTIVITĂTIII}

Tot timpul anului se desfășoară multiple activități precum: conferințe, expoziții, workshop-uri etc.

OPEN DAY este un eveniment anual la care am avut ocazia să particip, care s-a desfășurat sâmbătă, 6 aprilie 2019, la campusul Bovisa din Milano - un fel de târg de prezentare a tuturor facultăților din cadrul Universității către elevi și potențiali viitori studenți. Erau programate foarte multe prezentări ale diverselor secții ale universității în care profesorii prezentau audienței informații cu privire la specializarea respectivă, programul de invățământ aferent acesteia, modul de desfășurare a activităților în timpul studiilor și potențialul de dezvoltare profesională după terminarea studiilor, astfel încât cei interesați să poată să decidă ce vor studia și care sunt pașii pentru a-și atinge obiectivele. Orarul prezentărilor era realizat astfel încât mare parte din cadrele didactice puteau să prezinte, prin rotație, anumite secțiuni, fiindu-le permise interpretări sau intervenții personale, întrucât se punea mult accentul pe povestea personală și pe emoția transmisă publicului așa încât să se identifice cu dorințele lor și să ia decizia corectă pentru sine. De fapt, în cadrul Universității POLITECNICO DI MILANO (POLIMI), la fiecare început de an școlar, profesorii își fac o prezentare a cursurilor pe care le vor ține, astfel încât studenții să-și aleagă ce cursuri vor urma în anul universitar respectiv, deci prezentările publice a ofertei educaționale reprezintă o activitate uzuală și obligatorie a cadrelor didactice din cadrul POLIMI. În egală măsură erau implicați și studenți voluntari ai universității, care ghidau publicul, făceau înregistrări ale participanților la prelegerile din săli, ofereau informații vizitatorilor în cadrul expozițiilor interioare și a standurilor expoziționale din curtea exterioară etc. (Fig. 1, Fig. 2). 

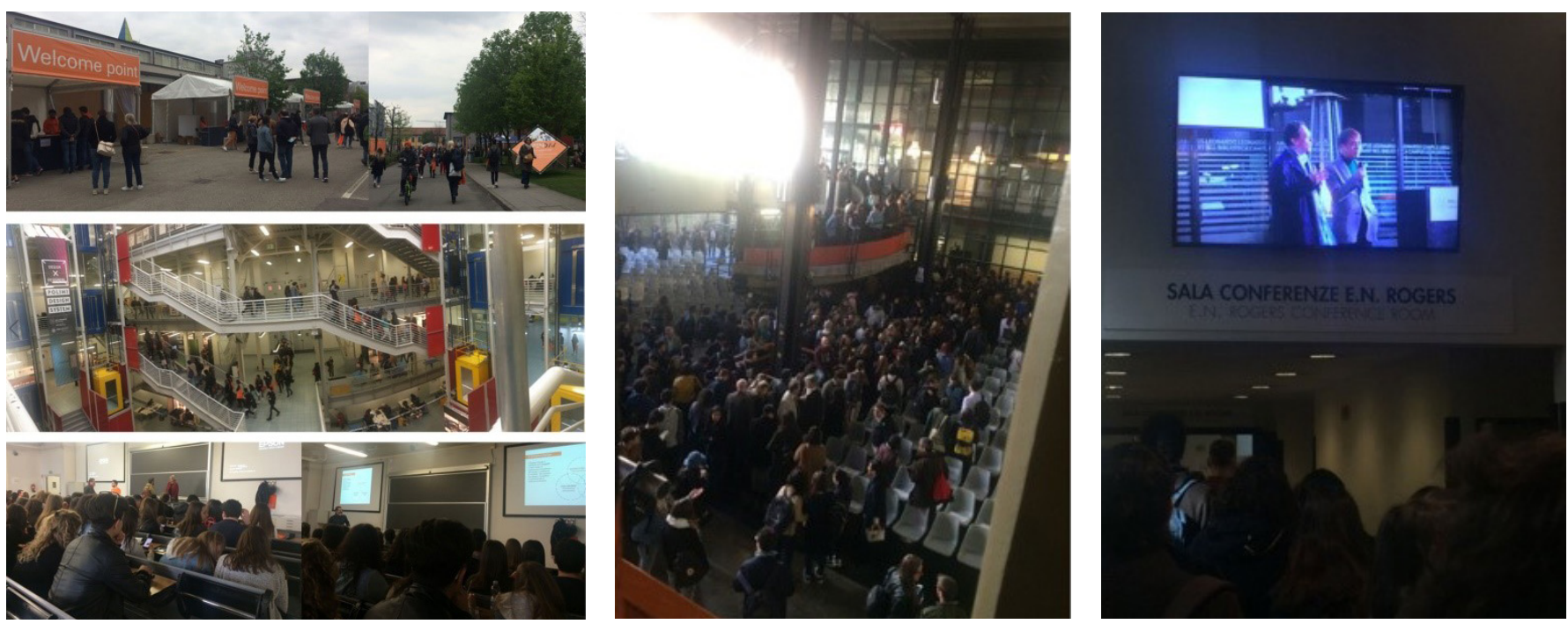

Fig. 2. Imagini de la evenimentul OPEN DAY din campusul Bovisa: standuri informationale în exterior, expoziții de proiecte în interior, prezentări și sesiuni de întrebări și răspunsuri în sălile de curs: dreapta - curtea interioară în care a avut loc prezentarea publică a árhitectului Tadao Ando și coada de la intrarea în sala de conferințe din interior (ecranul cu transmisiunea în direct fiind și acesta urmărit din holul clădirii). Surse foto: autorul

Unii studenți pot lucra 150 de ore anual în folosul universității, aceștia fie fiind plătiți, fie fiind scutiți de unele taxe (mi-a explicat un student voluntar pe care l-am întrebat despre modul în care s-au oferit ei să fie prezenți la acest eveniment ca voluntari). A fost o mare forță de muncă susținută atât de cadrele didactice, cât și de studenți, având în vedere că s-au înregistrat peste 14.000 de vizitatori în acea zi. Numărul mare de vizitatori este determinat și de faptul că admiterea se face o singură dată pe an, printr-un examen unic în toată Italia, în aceeași zi cu toate universitățile de același profil din țară, astfel că pentru viitorii studenți este o decizie foarte importantă încă din start să aleagă unde să studieze. Inclusiv studenții străini pot da admitere doar cu condiția să fie în Italia la data examenului.

TADAO ANDO a vorbit studenților de la facultatea de Arhitectură, Urbanism și Ingineria Construcțiilor din Milano (Leonardo) în data de 10 aprilie 2019. Oportuniteatea acestui eveniment a fost dată de expoziția "The Challenge" pe care Tadao Ando a inaugurat-o în aceeași perioadă la ARMANI/Silos din Milano, expoziție de arhitectură prezentând cele mai importante momente din cariera arhitectului, realizată în colaborare cu Centrul Pompidou, legată de evenimentul Salone del Mobile din 9-14 aprilie 2019. Participarea 
atât a cadrelor didactice, cât și a studenților a fost atât de mare încât conferința s-a desfășurat în spațiul curții interioare, fiind transmisă în direct și pe ecranele din sala de conferințe a clădirii. Ambele spații au fost pline, iar traficul îngreunat pe tot parcursul conferinței (Fig.2 dreapta). Am remarcat atât o abordare teoretică a unor idei și concepte aplicate în proiectele de arhitectură ale sale, cât și una practică și plină de învățături despre viață, fiind precizate multe informații personale legate de modul de lucru și de atitudini în situații diferite, atât critice, cât și hilare, care au dat savoare discurului, au mărit interesul și au sporit apropierea publicului, deschizându-l către dialog.

\section{„Doresc să creez 0 arhitectură care va trăi etern - nu în substanță sau formă, ci ca o amin- tire în inimile oamenilor." - Tadao Ando²}
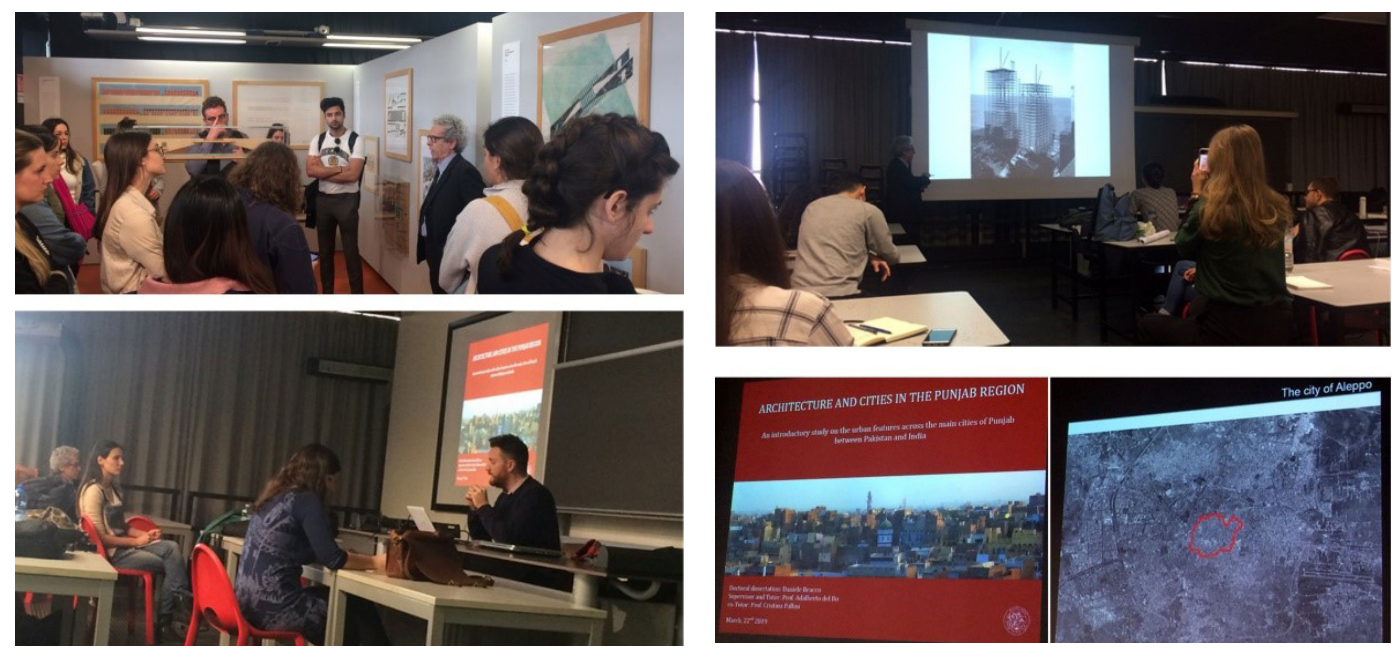

Fig. 3. imagini din timpul atelierului domnului prodecan prof. dr. arh. Adalberto Del Bo, îndrumător la Masterul de Arhitectura Construcțiilor, anul V, secția engleză: stânga - vizită la expoziție - sus, prezentare a unei teze de doctorat în cadrul atelierului - jos; dreapta - prelegere a domnului prof. dr. arh. Adalberto Del Bo - sus, imagini din prezentarea domnului drd. arh. Daniele Beacco - jos. Sursa foto: autorul

EXPOZIṬII nenumărate (am vizitat cel puțin 3 expoziții diferite în același spațiu expozițional, în perioada petrecută acolo) se organizează în permanență de către profesori sau studenți în sala de expoziții de la parterul clădirii. Expozițiile sunt deschise publicului larg, dar în același timp sunt utilizate de către cadrele didactice pentru a-și îndruma studenții pe parcursul orelor de atelier, utilizându-se de exemplificarea prin intermediul exponatelor pentru a sugera metode de prezentare (desen, machete) dar și metode teoretice de abordare a ideilor și conceptelor de arhitectură exemplificate prin soluțiile expuse (Fig. 3 stânga sus). 
PREZENTĂRI ale unor diverse subiecte teoretice de arhitectură aveau loc atât la nivelul școlii, fiind anunțate prin intermediul afișelor informative de la intrarea în școală, cât și în cadrul atelierelor, unde nu doar profesorii atelierului respectiv, dar și speakerii invitați prezentau subiecte în relație cu temele de proiectare (Fig.3 stânga jos - prezentarea unei teze de doctorat în cadrul unui atelier de proiectare având o temă de studiu în concordanță cu subiectul studiat, constituind și un bun exercițiu pentru studentul doctorand înainte de susținerea tezei în cadrul comisiei).

\section{PROIECTARE}

Pe parcursul perioadei pe care am petrecut-o acolo am participat la mai multe ateliere de proiectare din ani diferiți, la secții diferite, a unor profesori diferiți, pentru a putea experimenta mai multe activități similare la care să pot observa asemănări și deosebiri, atât între atelierele lor, cât și între atelierele universității lor și ale universității noastre. În acest sens, având în vedere că activitatea de proiectare, conform orarului, se desfășura într-o singură zi pe săptămână, de la 9:00 la 19:00 (cu pauză de masă de 1 oră la prânz), am putut participa, în zile diferite ale saptămânii, la atelierul domnului prodecan prof. dr.arh. Adalberto Del Bo (anul V, Masterul de Arhitectura Construcțiilor, secția engleză, care aveau ca temă de proiectare reconstrucția orașului Aleppo din Siria), la atelierul domnului prof.dr.arh. Gennaro Postiglione (anul III, Arhitectură - Licență, secția engleză, care studiau o un cartier din Milano, tema fiind "Gratosoglio. Ground. Zero. 2019"), precum și la atelierul domnului prof.dr.arh. Luca Basso Peressut (anul IV, Masterul de Arhitectura Mediului Construit Interior, secția italiană, ce construiau, ca temă, casa unui colecționar de artă în Milano). În timpul liber, atât la școală cât și online, împreună cu domnul prof.dr.arh. Adalberto Del Bo am îndrumat și câteva proiecte de Diplomă (3 proiecte de ansambluri rezidențiale ale unor studenți din Turcia și China, un proiect de spațiu cultural cu sală de teatru ale unor studente din Turcia și un proiect de centru cultural cu spațiu muzeal al unei studente din Liban).

Studenții lucrau în echipe de câte 3 la toate proiectele, pe tot parcursul studiilor, inclusiv la proiectele de Diplomă. În condiții extreme, în cazul în care unele echipe se dovedeau a fi disfuncționale, se acceptau, de comun acord cu profesorii îndrumători, ca acestea să se divizeze, rămânând echipe de 2 și/sau un student. Lucrul în echipă și programul de lucru de o săptămână între două ședințe consecutive de atelier, făceau posibil ca progresul studenților de la o săptămână la alta să fie notabil.

În timpul atelierului, prima parte a zilei era utilizată pentru prezentări ale profesorilor sau invitaților lor, cu prelegeri pe marginea subiectului de studiu, fie ale echipelor de 
studenți, cu prezentări ale etapelor de lucru la proiect la momentul respectiv. în pauza de masă, obiceiul era ca întreg colectivul de îndrumători să meargă împreună la masă, pe la diversele restaurante din zonă. în a doua parte a zilei se făceau corecturi la proiecte, iar la finalul zilei de atelier profesorii specificau care sunt cerințele pentru ședința următoare, astfel că studenții știau foarte clar ce pași urmează să facă la proiectele lor.

\section{ATELIER ANUL V, MASTER ARHITECTURA CONSTRUCT,IILOR, ENGLEZĂ}

Proiectul de reconstrucție a orașului Aleppo din Siria punea probleme atât de abordare urbanistică, dar și studiu istoric și teorie de arhitectură a spațiului cu specificul din zonă, astfel că prelegerile din cadrul atelierului tratau aceste direcții diferite, ajutându-i pe studenți să aprofundeze anumite aspecte, să decidă direcția abordării și să clarifice argumentele pentru solițiile lor (Fig. 3). La îndrumarea proiectului participa și o studentă doctorand din Siria, care cunoștea foarte bine orașul Aleppo și avea cunoștințele și experiența locală, ajutând foarte mult studenții cu explicații legate de tradiție, istorie, specificul locului etc.

\section{ATELIER ANUL III, LICENTŢA ARHITECTURĂ, ENGLEZĂ}

Proiectul de la atelierul domnului prof.dr.arh. Gennaro Postiglione avea o temă foarte clar structurată, studenților cerându-li-se să lucreze într-o anumită manieră, pe formate de planșe predesenate de autorul temei, urmărindu-se ca proiectul final să reprezinte o hartă imensă compusă din toate proiectele studenților, care să constituie obiectul unei expoziții publice la finalul semestrului. Modul de cercetare și prezentare era, așadar, unul unitar. Fiecare echipă de studenți aborda tema studiind un alt loc din cadrul zonei de studiu. (Fig. 4 stânga)

În prima parte a zilei studenții își prezentau proiectele în echipă și primeau feedback de la toți profesorii (inclusiv cei specialiști în alte discipline integrate în cadrul proiectului - de exemplu fotografie sau sociologie), iar în a doua parte urmau corecturile la proiecte cu îndrumătorul principal și câțiva asistenți doctoranzi străini. (Fig.4 dreapta) 

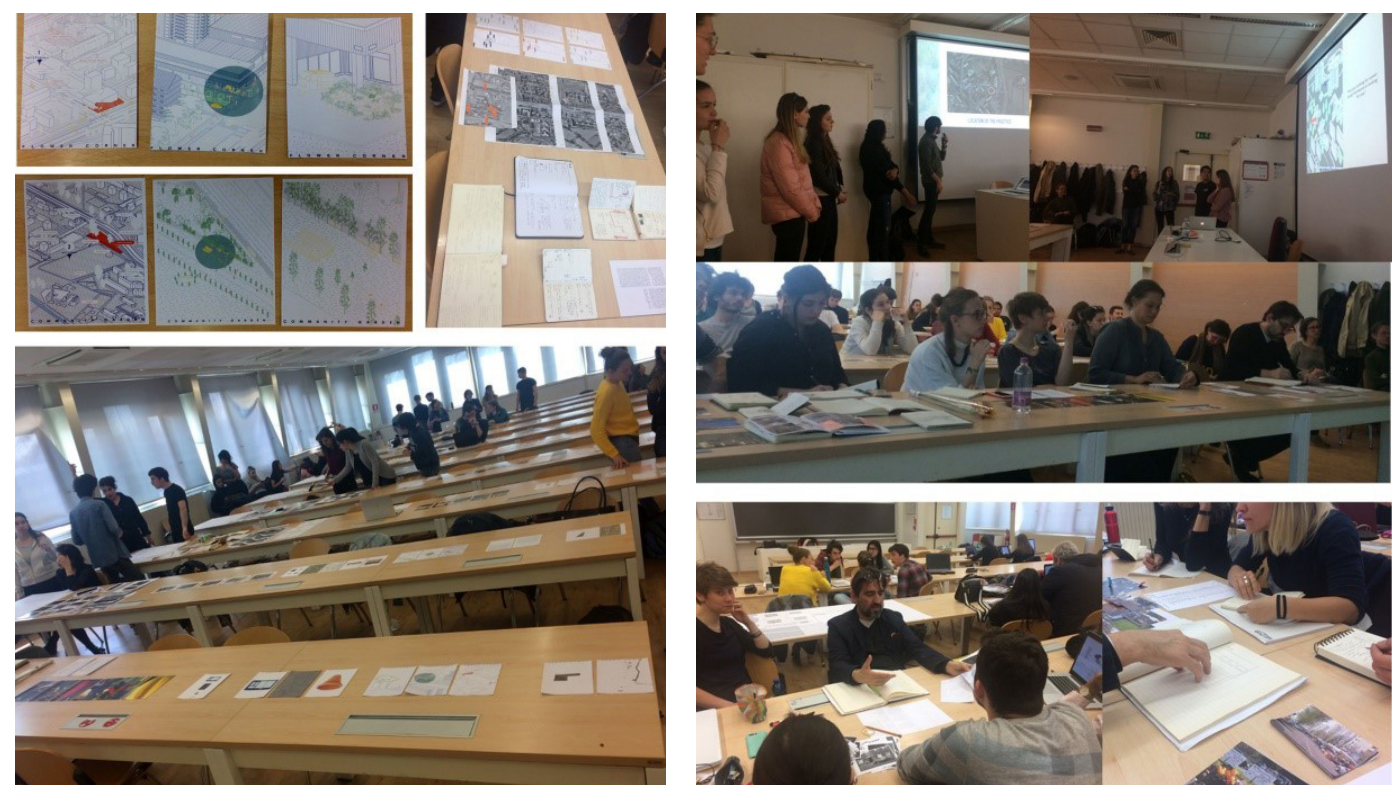

Fig. 4. imagini din timpul atelierului domnului prof. dr. arh. Gennaro Postiglione, îndrumător la Arhitectură (Licență), anul III, secția engleză: stânga - extras din tema și imagini ale proiectelor studenților prezentate pentru corecturi; dreapta - prezentări de proiect ale studenților în fața tuturor cadrelór didactice și colegilor - sus, imagini din timpul corecturilor - jos. Surse fóto: autorul

\section{ATELIER ANUL IV, MASTER DE ARHITECTURA MEDIULUI CONSTRUIT INTERIOR, ITALIANĂ}

Atelierul domnului prof. dr. arh. Luca Basso Peressut se desfășura în limba italiană, chiar dacă și aici erau studenți străini din Franța și Spania, dar și ei vorbeau italiană. Tema proiectului propunea o locuință a unui colecționar de artă în Milano, studenții având de proiectat atât construcția clădirii (amplasată între două calcane și două străzi, de-a lungul unui canal de apa din zona de sud a orașului), cât și interiorul ce trebuia să pună în evidență colecția de obiecte de artă propusă de către studenți, așa încât, pe perioada de timp cât colecționarul nu locuia în țară, colecția sa să poată fi accesibilă publicului printr-un program de vizite. 
În același mod ca în cazul celorlalte ateliere, în prima parte a zilei studenții își prezentau proiectele, iar în a doua parte a zilei se făceau corecturile (Fig.5). Spre deosebire de celelalte ateliere, am observat că aici participau toți studenții la toate corecturile proiectelor, astfel că informațiile se transmiteau mult mai ușor tuturor, iar în aceeași perioadă de timp se discutau mult mai multe idei și aspecte, în loc să se repete anumite observații identice mai multor echipe, fiecăreia în parte. Studenții lucrau cu documentații organizate în planșe de prezentare și slide-uri ppt, cu machete, pe calculator etc. și își luau tot timpul notițe ori de câte ori li se făceau sugestii lor sau altor colegi.
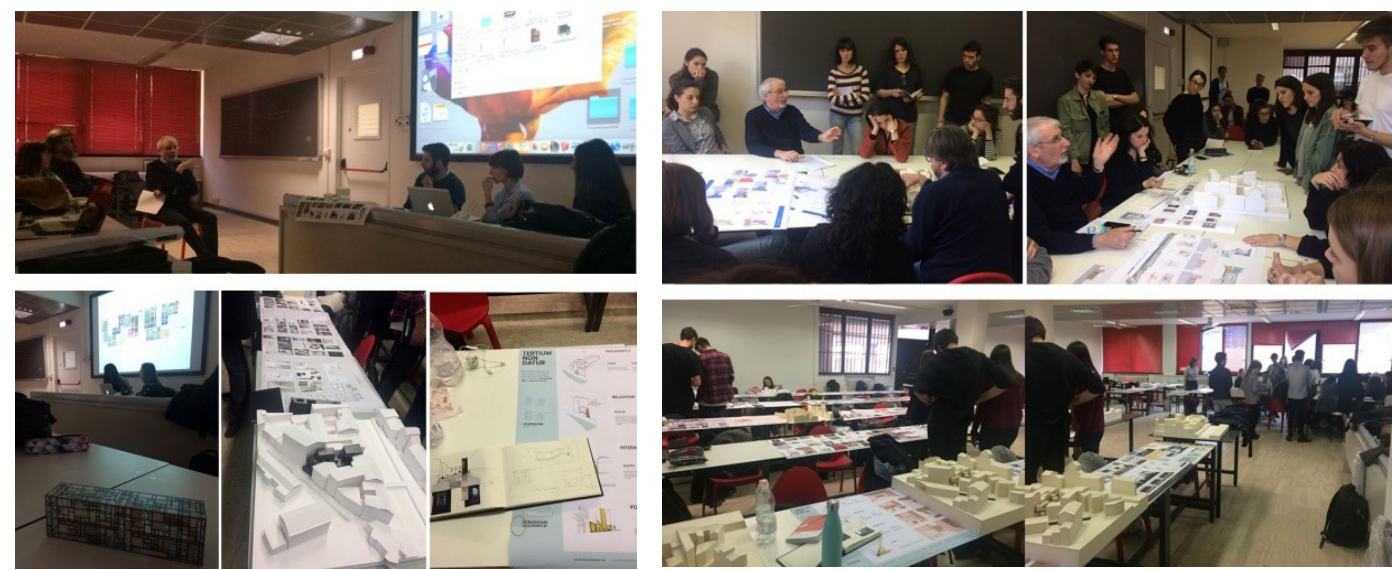

Fig. 5. imagini din timpul atelierului domnului prof. dr. arh. Luca Basso Peressut, indrumător la Masterul de Arhitectura Mediului Construit Interior, anul IV, italiană: stânga - prezentări de proiecte; dreapta - corecturi la proiecte. Surse foto: autorul

\section{PROIECTE DE DIPLOMĂ}

Studenții care lucrau la proiectele de Diplomă singuri sau în echipe făceau corecturi cu îndrumătorul de diplomă în afara orelor de program, de obicei în zilele acestora de atelier. Alături de domnul prof.dr.arh. Adalberto Del Bo, am colaborat la îndrumarea câtorva proiecte, cu unii dintre studenți colaborând și online, pentru a-i ajuta cu diverse informații, surse de documentare și detalii.

Deasemenea, am avut ocazia să asist și la corecturi ale domnului prof. dr. arh. Luca Basso Peressut. (Fig. 6) 

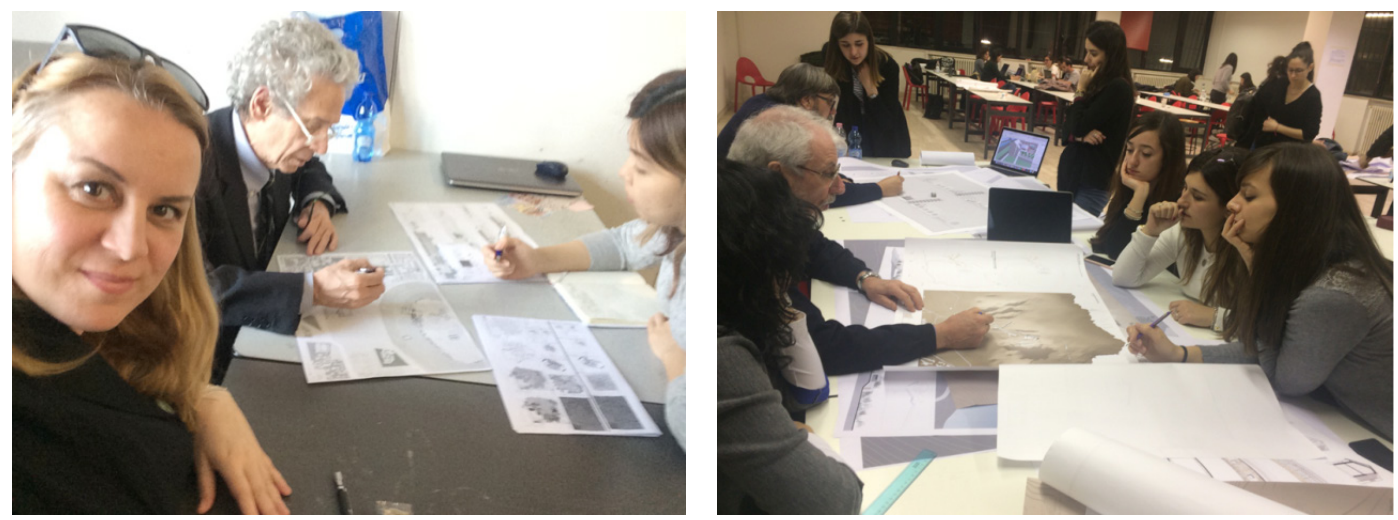

Fig. 6. Corecturi proiecte de Diplomă - împreună cu prof. dr. arh. Adalberto Del Bo, stânga; prof. dr. arh. Luca Basso, dreapta. Surse foto: autorul.

\section{ATMOSFERA DE LUCRU LA PROIECTE ÎN ȘCOALĂ}

Deși orarul dedică numai 1 zi pe săptămână atelierului de proiectare, faptul că studenții lucrează în echipe la proiecte și că au suficient timp de lucru alocat pentru această activitate, face ca zilnic toate spațiile de lucru din întreaga școală să fie pline de mese de lucru ocupate: în ateliere, pe coridoare, pe terase, în cantine, în biblioteci etc. (Fig. 7)
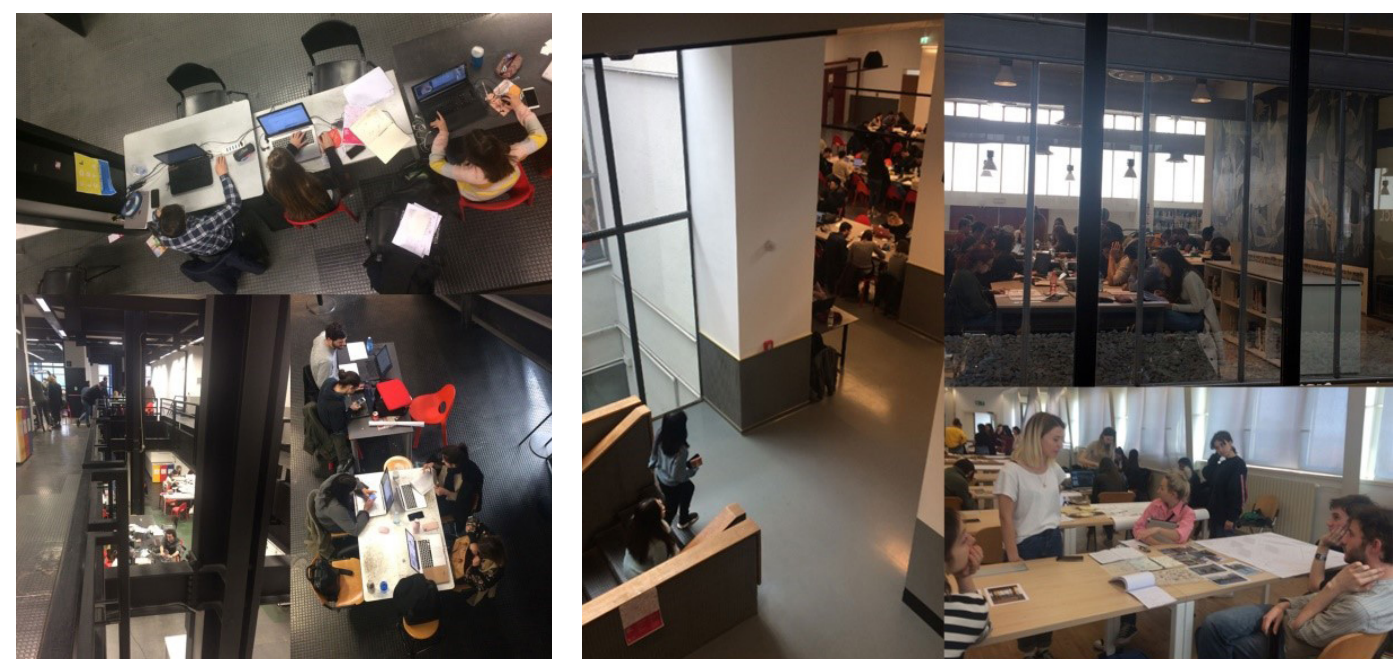

Fig. 7. stânga - atmosfera de lucru pe holurile facultății; dreapta - atmosfera de lucru în cantină, la bibliotecă și în ateliere. Surse foto: autorul 


\section{CONCLUZII}

Am sesizat un program mai relaxat pentru studenți, având în vedere că lucrează la 1 singur proiect pe semestru, cu câte 1 singură întâlnire săptămânală, în echipe de câte 3 persoane și având restul cursurilor relaționate, în cea mai mare măsură, cu proiectul. Acest mod de lucru face ca focusul lor și productivitatea să fie foarte crescute, putând să evolueze mult de la o săptămână la alta cu lucrul la proiect. în egală măsură am putut observa claritatea cerințelor îndrumătorilor de la o corectură la alta și consecvența acestora în reacția lor la răspunsurile studenților. Per total se poate observa o atmosferă constructivă și un mod de lucru profesional, care nu încurajează scuzele de niciun fel ci asumarea responsabilității. Din discuțiile cu secretarul șef și cu cadrele didactice cu care am colaborat am înțeles că titularii au obligativitatea de a asigura un anumit număr de ore didactice anual, desfășurând activitate de cercetare în cadrul școlii pâna la completarea normelor, legea din Italia nepermițând cadrelor didactice să profeseze în afara Universității pentru a nu face concurență arhitecților din piață, iar Universitatea primind pentru cercetare proiecte de la Primăria orașului și alte instituții de stat, precum și fonduri europene alocate pentru cercetare.

De asemenea, dintr-o directivă eu ropeană, de câțiva ani se pune accentul pe comunicarea eficientă și profesională, astfel că există obligativitatea atât a cadrelor didactice, cât și a studenților să urmeze cursuri de specialitate în domeniu, aceștia din urmă având în mod obligatoriu câte 1 credit ETCS din proiect alocat strict pentru modul de prezentare atât vizual, cât și la nivelul susținerii publice a proiectului în fața juriului.

Anul I este un an comun, pentru toate specialitățile, fiind considerat ca cel mai greu an - conform spuselor secretarului șef, peste 15\% dintre studenți renunță la facultate încă din primul an datorită unor materii precum matematica sau statica. Față de numărul de studenți admiși într-un an școlar, doar cca.50\% din generația respectivă termină studiile în mod normal, restul rămân cu cel puțin încă 1 semestru de studii de recuperat pentru a termina facultatea (având voie să refacă maxim câte 1 an, câte 1 singură dată - adică Licența de 3 ani o pot termina în maxim 6 ani).

\section{REFERINȚE}

POLITECNICO DI MILANO, Arhitectural Programmes - School of Architecture, Urban Planning, Construction Engineering, pag. 10.

TADAO ANDO, The Challenge, 9-28 aprilie 2019, Armani/Silos, Milano, https://www.armanisilos.com/exhibition/tadao-ando-the-challenge/ 